\title{
Looking Back and Looking Forward at Stuff
}

\section{Infectious Myositis}

\author{
Sireesha Murala $\mathrm{MD}^{1}$, Arun Ram $\mathrm{MD}^{2}$, Rajendran \\ Vijayakumar $\mathrm{PhD}^{3}$, Elanagan Nagarajan $\mathrm{MD}^{4}$ \\ 'Department of Neurology, University of Missouri, \\ Columbia, Missouri. \\ ${ }^{2}$ Department of Physiological Sciences, East Virginia \\ Medical School, Norfolk, Virginia. \\ ${ }^{3}$ Department of Biology, College of Science in Zulfi, \\ Majmaah, Saudi Arabia. \\ ${ }^{4}$ Department of Neurology, Albany Medical Center, \\ Albany, New York.
}

\section{Introduction}

Infectious myositis (IM), is the infection of the skeletal muscle tissue (particularly voluntary muscle), which is characterized by swelling, pain, tenderness, and/or weakness. Infection of the skeletal muscle is atypical and is caused by various agents like bacteria, mycobacteria, viruses, parasitic, and fungal organisms. Among all the agents, the most common cause of infectious myositis is bacteria (frequently by staphylococcal and streptococcal species). ${ }^{1-4}$

Myositis is of different causes and non-infectious causes of myositis are shown below in Table $1 .^{5-7}$ This review does not cover the topic of noninfectious myositis. Infectious myositis is caused by various pathogens like bacteria, viruses, fungi, and parasites. Different causative agents of infective myositis are shown below in Table 2.,6,8,9 The following section will further discuss bacterial myositis.
Table 1. Non-infectious myositis causes ${ }^{5,6}$

Idiopathic inflammatory myopathies

- Polymyositis

- Dermatomyositis

- Inclusion body myositis

- Myositis associated with collagen vascular diseases

o Polyarteritis nodosum

o Wegener's granulomatosis

o Systemic lupus erythematosus

o Sjogren's syndrome

o Rheumatoid arthritis

o Scleroderma

o Polymyalgia rheumatica

o Mixed connective tissue disease

o Adult Still's disease

o Vasculitis - leukocytoclastic, hypersensitivity

- Myositis associated with malignancies

Other forms of inflammatory myopathies

- Myositis associated with eosinophilia

- Myositis ossificans

- $\quad$ Giant-cell myositis

Myopathies caused by medications and toxins

Metabolic myopathies

- Inborn errors of metabolism

o Disorders in glycogen metabolism

o Lipid storage disorders

o Mitochondrial myopathies

Endocrine disorders

- Hypo- and hyperthyroidism

- Acromegaly

- Addison's disease

- Cushing syndrome

- Hyperaldosteronism

- Hyperparathyroidism

Electrolyte abnormalities

Nutritional deficiency

Diseases that may cause myopathic symptoms

- Neuropathic disorders

- Muscular dystrophies

- Other diseases of the neuromuscular junction

Medication-related adverse effects

Other causes

- Sarcoidosis

- Amyloidosis

- Behcet's disease

- Atherosclerotic emboli 
Table 2: Causes of infectious myositis ${ }^{4,6,8,9}$ Infectious organism Organisms group

\begin{tabular}{|c|c|}
\hline $\begin{array}{l}\text { Gram-positive } \\
\text { bacteria }\end{array}$ & $\begin{array}{l}\text { Staphylococcus aureus } \\
\text { Group A Streptococcus } \\
\text { Streptococcus (groups A, B, } \\
\text { C and } G, S . \text { pneumonia, } S . \\
\text { anginosus) }\end{array}$ \\
\hline $\begin{array}{l}\text { Gram-negative } \\
\text { bacteria }\end{array}$ & $\begin{array}{l}\text { Aeromonas hydrophila } \\
\text { Burkholderia mallei, B. } \\
\text { pseudomallei } \\
\text { Citrobacter freundii } \\
\text { Enterobacter SPP } \\
\text { Haemophilus influenzae } \\
\text { Klebsiella oxytoca, K. } \\
\text { pneumoniae } \\
\text { Morganella morganii } \\
\text { Neisseria gonorrhoeae } \\
\text { Pasteurella spp } \\
\text { Proteus spp } \\
\text { Pseudomonas spp } \\
\text { Salmonella spp } \\
\text { Serratia marcescens } \\
\text { Vibrio vulnificus } \\
\text { Yersinia enterocolitica }\end{array}$ \\
\hline Anaerobic bacteria & $\begin{array}{l}\text { Bacteroides spp } \\
\text { Clostridium spp } \\
\text { Fusobacterium necrophorum and } \\
\text { F. nucleatum } \\
\text { Streptococcus spp (anaerobic, } \\
\text { e.g., Peptostreptococcus) } \\
\text { Veillonella spp }\end{array}$ \\
\hline Mycobacterium spp & $\begin{array}{l}\text { Mycobacterium avium complex } \\
\text { Mycobacterium bovis } \\
\text { Mycobacterium haemophilum } \\
\text { Mycobacterium leprae } \\
\text { Mycobacterium tuberculosis }\end{array}$ \\
\hline Atypical bacteria & $\begin{array}{l}\text { Actinomyces spp } \\
\text { Bacillus spp } \\
\text { Bartonella spp } \\
\text { Borrelia burdorferi } \\
\text { Brucella spp } \\
\text { Coxiella burnetti } \\
\text { Francisella tularensis } \\
\text { Legionella pneumophila } \\
\text { Leptospira spp } \\
\text { Mycoplasma pneumoniae } \\
\text { Nocardia spp } \\
\text { Rickettsia and R. conorii } \\
\text { Treponema pallidum }\end{array}$ \\
\hline
\end{tabular}

\begin{tabular}{|c|c|}
\hline $\begin{array}{l}\text { Infectious organism } \\
\text { group }\end{array}$ & Organisms \\
\hline Viruses & $\begin{array}{l}\text { Adenovirus } \\
\text { Cytomegalovirus } \\
\text { Dengue virus } \\
\text { Enteroviruses (Coxsackie B virus } \\
\text { and ECHO virus) } \\
\text { Epstein-Barr virus } \\
\text { Hepatitis A, B, and C viruses } \\
\text { Herpes simplex virus } \\
\text { HIV } \\
\text { HTLV-1 } \\
\text { Influenza A and B viruses } \\
\text { Mumps virus } \\
\text { Parainfluenza virus } \\
\text { Parvovirus B19 } \\
\text { SARS-Coronavirus (COVID-19) } \\
\text { Varicella-zoster virus } \\
\text { West Nile virus }\end{array}$ \\
\hline Fungi & $\begin{array}{l}\text { Aspergillus spp } \\
\text { Blastomyces dermatitidis } \\
\text { Candida spp } \\
\text { Coccidioides spp } \\
\text { Cryptococcus neoformans } \\
\text { Fusarium spp } \\
\text { Histoplasma capsulatum } \\
\text { Mucormycosis } \\
\text { Pneumocystis jirovecii } \\
\text { Sporothrix schenckii }\end{array}$ \\
\hline Parasites & $\begin{array}{l}\text { Entamoeba histolytica } \\
\text { Echinococcus spp } \\
\text { Haycocknema perplexum } \\
\text { Microspordia spp (Annicaliia, } \\
\text { Trachipleistophora, Pleistophora) } \\
\text { Onchocerca volvulus } \\
\text { Plasmodium spp } \\
\text { Sarcocystis spp } \\
\text { Schistosoma spp } \\
\text { Spirometra mansonoides } \\
\text { Taenia solium } \\
\text { Toxocara canis } \\
\text { Toxoplasma gondii } \\
\text { Trichinella spp } \\
\text { Trypanosoma cruzi }\end{array}$ \\
\hline
\end{tabular}

COVID-19, coronavirus-19; ECHO, enteric cytopathogenic human orphan viruses; HIV, human immunodeficiency virus; HTLV-1, human T-cell leukemia-lymphoma virus type 1; SARS severe acute respiratory syndrome. 


\section{Bacterial infections of the musculature}

Bacterial myositis is rather uncommon. Various routes of infection include a contiguous site of infection, vascular insufficiency, penetrating trauma, and hematogenous dissemination. Acute bacterial myositis is most commonly caused by Staphylococcus aureus. Myositis cause (bacterial or other forms) should be established before initiating the management of cases. Various categories of bacterial pyogenic infections of the musculature are shown below in Table 3.,1,6

Table 3: Various categories of bacterial pyogenic infections of the musculature ${ }^{6}$

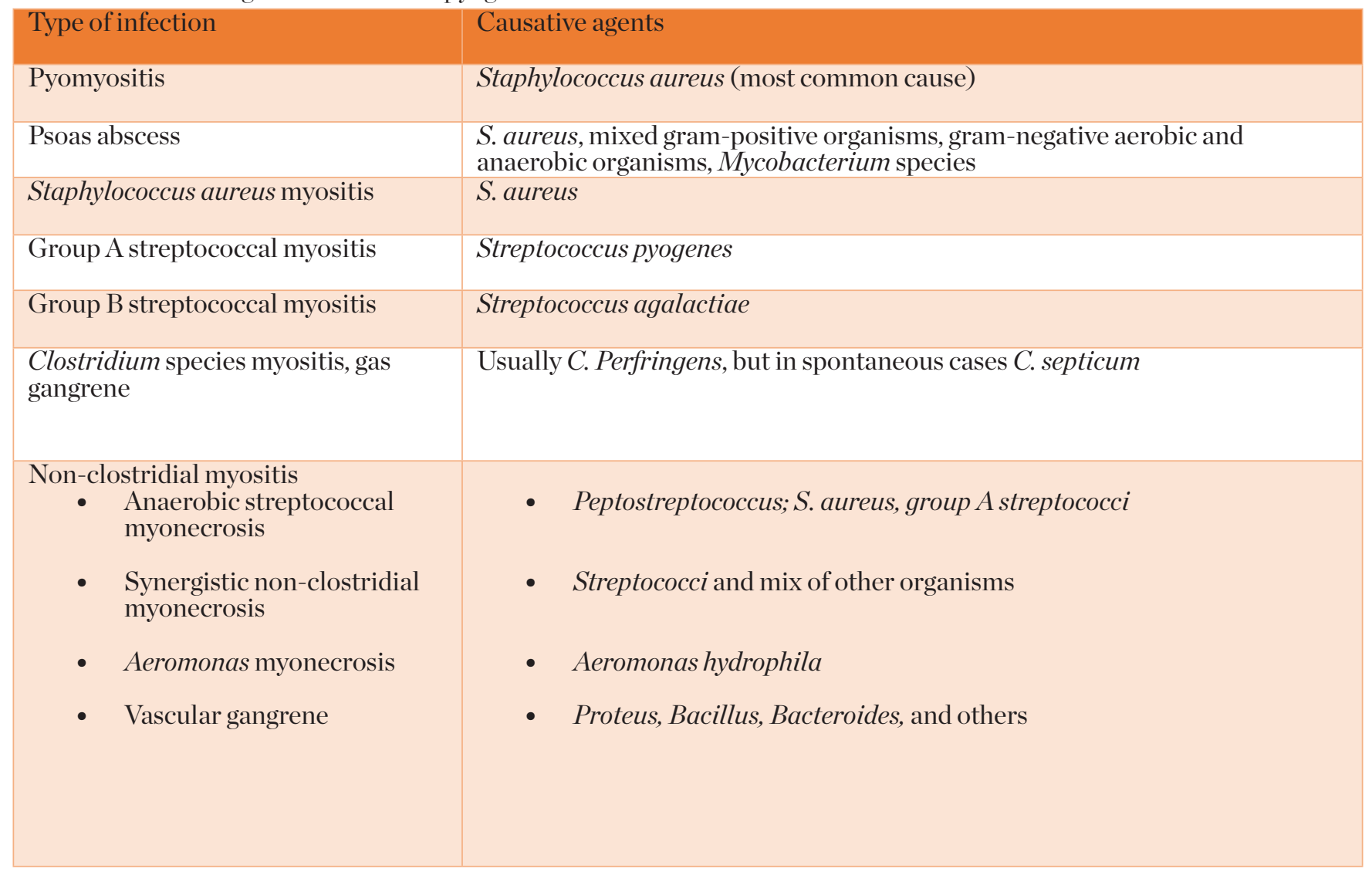




\section{Purulent Infectious Myositis (PIM or Pyomyositis)}

Purulent infectious myositis (PIM) is a subacute infection of the axial skeletal muscles which is neither a contiguous infection of the bone or soft tissue nor due to a penetrating injury. ${ }^{6,10}$ Even though, pyomyositis was considered a "tropical disease" earlier, the cases are well reported in temperate regions., ${ }^{3,11}$

Recent theory in the pathogenesis of PIM suggested transient bacteremia in the presence of muscle injury. As the healthy muscle is resistant to infection, bacteremia without associated muscle damage is improbable. ${ }^{6,12}$ Less than $0.5 \%$ of the cases of staphylococcal bacteremia developed PIM, demonstrating that muscular damage or other pathology should be present to develop PIM. ${ }^{6,13}$

Young males in their second to the fourth decade of life are most susceptible to work injuries. Most of the patients also have a history of excessive exercise (especially in young athletes), carried out a couple of days or hours, before developing PIM..$^{10,14}$ Predisposing factors for PIM are shown below in Table $4 .^{10}$

Table 4: Predisposing factors for purulent infectious myositis ${ }^{10}$

\begin{tabular}{|c|c|}
\hline Conditions & Predisposing factors \\
\hline General conditions & $\begin{array}{ll}\text { - } & \text { Cancer } \\
\text { - } & \text { Chronic liver/renal disease/failure } \\
\text { - } & \text { Diabetes mellitus } \\
\text { - } & \text { Malnutrition } \\
\text { - } & \text { Organ transplantation } \\
\text { - } & \text { Postpartum/post-abortion } \\
\text { - } & \text { Trauma (overuse in athletes) }\end{array}$ \\
\hline Rheumatologic conditions & $\begin{array}{ll}\text { - } & \text { Dermatomyositis } \\
\text { - } & \text { Polyangiitis } \\
\text { - } & \text { Progressive systemic sclerosis } \\
\text { - } & \text { Sheumatoid arthritis } \\
\text { Systemic lupus erythematosus }\end{array}$ \\
\hline Immunodeficiency conditions & $\begin{array}{ll}\text { - } & \text { Agammaglobulinemia } \\
\text { - } & \text { Chronic granulomatous disease } \\
\text { - } & \text { Dyclic neutropenia } \\
\text { - } & \text { HIV infection / AIDS } \\
\text { - } & \text { HTLV } 1 / 2 \text { infection } \\
\text { Myeloperoxidase deficiency }\end{array}$ \\
\hline Hematologic conditions & $\begin{array}{ll}\text { - } & \text { ALL, AML, CML, PmL } \\
\text { - } & \text { Aplastic anemia } \\
\text { - } & \text { ßThalassemia } \\
\text { - } & \text { Felty's syndrome } \\
\text { - } & \text { Myelodysplastic syndrome } \\
\text { - } & \text { Multiple myeloma } \\
\text { - } & \text { Sick-Hode cell disease } \\
\text { - } & \text { Sub-clinical leukemia }\end{array}$ \\
\hline Medications & $\begin{array}{ll}\text { - } & \text { Anabolic steroids, Glucocorticoids (chronically) } \\
\text { - } & \text { Certolizumab pegol } \\
\text { - } & \text { Chemotherapy } \\
\text { - } & \text { Lefluximabomide } \\
\text { - } & \text { Tocilizumab }\end{array}$ \\
\hline
\end{tabular}

ALL, Acute lymphoblastic leukemia; AML, Acute myeloblastic leukemia; CML, Chronic myeloblastic leukemia; PmL, Promyelocytic leukemia; HIV, Human immunodeficiency virus; AIDS, Acquired immunodeficiency syndrome; HTLV, Human T-cell lympho-trophic virus; IV, Intravenous. 
Table 5: Purulent infectious myositis clinical stages and management ${ }^{10,20}$

\begin{tabular}{|c|c|c|}
\hline Stage of disease & Clinical characteristics & Management plan \\
\hline Stage 1 - Invasive & $\begin{array}{l}\text { - } \quad \text { Typically lasts 10-21 days } \\
\text { - } \quad \text { Insidious onset of dull muscle pain, low-grade fe- } \\
\text { ver, myalgia, malaise, cramps, anorexia } \\
\text { - } \quad \text { Localized edema (woody induration) } \\
\text { - } \quad \text { Little or no muscular tenderness } \\
\text { - Only a small portion of patients present at this } \\
\text { stage }\end{array}$ & Antimicrobial treatment \\
\hline $\begin{array}{l}\text { Stage } 2 \text { - Purulent or } \\
\text { Suppurative }\end{array}$ & $\begin{array}{ll}\text { - } & \text { Duration from } 24 \mathrm{~h} \text { to } 12 \text { days } \\
\text { - } & \text { Fever and chills } \\
\text { - } & \text { Abscess formation, muscular mass/swelling is vis- } \\
\text { ible with diagnostic techniques } \\
\text { - } & \text { Tender muscles } \\
\text { - } & \text { Most patients present in this stage }\end{array}$ & $\begin{array}{l}\text { Antimicrobial therapy + drainage } \\
\text { of intramuscular collections or } \\
\text { incipient abscesses (drainage } \\
\text { through percutaneous route or } \\
\text { open surgery) }\end{array}$ \\
\hline Stage 3 - Late stage & $\begin{array}{l}\text { - High fever, severe pain, infection signs locally, and } \\
\text { systemic symptoms of sepsis } \\
\text { Progressed to septicemia, metastatic abscesses, and } \\
\text { multi-organ dysfunction which can lead to mortal- } \\
\text { ity } \\
\text { - Few patients present at this stage }\end{array}$ & $\begin{array}{l}\text { Antimicrobial therapy }+ \\
\text { intramuscular abscess excision } \\
\text { (open surgery) }\end{array}$ \\
\hline
\end{tabular}

Different PIM classification methods were recommended. Based on the area of the world as tropical vs non-tropical. Based on the route of infection, as primary or secondary. Primary PIM includes cases developing from bacteremia, while secondary PIM involves cases through continuous spread from either bone or soft tissue. ${ }^{10,15-17}$ PIM is categorized based on the muscle groups involved as cervical, para-spinal, thoraco-abdominal, pelvic, and lower extremities, further as multifocal or generalized myositis..$^{10,18,19}$

PIM staging is based on the progression of the infection from the early stages of bacterial seeding in the muscle to the late stages. PIM clinical stages and their management are shown below in Table 5. ${ }^{10,20}$ Diagnosis of PIM in the early stages might be difficult because of subtle skin and other systemic examination findings and has a high chance of misdiagnosing the condition. ${ }^{10}$

For osteoarticular complications, radiographs are used in making the diagnosis of PIM. Intramuscular collections are diagnosed by ultrasound, contrast computed tomography (CT), and magnetic resonance imaging (MRI), for deep infections of the thorax, abdomen, and pelvis. ${ }^{10,21}$

Antimicrobials treatment should include a combination therapy to target gram-positive, gram-negative aerobe, and anaerobic microorganisms like third or fourthgeneration cephalosporins (ceftazidime or cefepime) along with anaerobic coverage (metronidazole), beta-lactams (piperacillin/tazobactam) or carbapenem and clindamycin in toxic shock (Group A Streptococci). 10,20,22

\section{Psoas Abscess}

Psoas abscess is caused by a purulent infectious collection in the psoas muscle, either unilaterally or bilaterally. Psoas abscess is called primary when it is due to an occult hematogenous spread (S. aureus) and secondary when it is due to a contiguous spread from other locations. ${ }^{6,23}$

The main cause of psoas abscess used to be Mycobacterium tuberculosis (Pott's disease) infections, which were spreading between vertebrae and psoas muscles. Recently, these are mainly seen in immunocompromised patients (chemotherapy or HIV). Secondary psoas abscesses are due to the spread of gastrointestinal and genitourinary infections. The most common age group affected are from 30 to 50 years of age. ${ }^{6,24,25}$

Recently, primary psoas abscess is caused by community-acquired MRSA and other pathogens like S. pneumoniae, S. milleri, and group A streptococcus. Gramnegative organisms like Escherichia coli, Pseudomonas, Haemophilus, Proteus, and Pasteurella species rarely cause the primary psoas abscess. Risk factors include diabetic patients, alcoholics, the elderly, and the immunocompromised. ${ }^{6,26,27}$

High vigilance is required while diagnosing a psoas abscess. The classical triad of pain, fever, and limp is often absent. Other symptoms that are commonly seen are back pain, flank pain, groin mass or fullness, limp, malaise, anorexia, and weight loss. ${ }^{6,26,27}$ Lab testing shows leukocytosis, anemia, and elevated erythrocyte sedimentation rate. CT or MRI are used in diagnosing the 
psoas abscess. ${ }^{6}$

Management includes intravenous antibiotics and surgical drainage. Open surgical drainage or CT-guided percutaneous drainage is done based on the volume and number of the abscesses. ${ }^{6,28}$ For secondary psoas abscesses, combined management of gastrointestinal or genitourinary infections along with debridement and drainage abscess prevents the recurrence of the infection. ${ }^{6,29}$

Psoas abscess along with spinal infection should get a spinal surgery to prevent spinal instability, spinal cord compression, and other neurological deficits. Antibiotic therapy should include agents against enteric gram-negative and anaerobes, along with beta-lactams (piperacillintazobactam, carbapenem). Vancomycin should be used for community-acquired MRSA. Antibiotics are ideally given for 3 weeks after drainage, often continued for 4 to 6 weeks. For M. tuberculosis, therapy with four-drug anti-tuberculosis drugs should be continued for 6 months. Primary psoas abscess has a good prognosis and a mortality rate of $2 \%$, while secondary psoas abscess has a mortality rate of $20 \%, 6,28,30,31$

\section{Bacterial myositis}

Acute bacterial myositis is the diffuse infection of the muscle without an intramuscular abscess. It is commonly seen in adults and is reported less frequently than PIM and psoas abscess. Gram-positive organisms (Streptococcus), are the most frequent cause of myositis. ${ }^{6,32}$

\section{Staphylococcus aureus myositis}

Staphylococcus aureus often causes diffuse myositis along with rhabdomyolysis. Creatine kinase levels will be elevated (unlike PIM), along with CRP levels. Vancomycin or Daptomycin should be included in the management plan to target MRSA. Abscess and dead tissue are removed through surgical debridement and vacuum-assisted closure (VAC) of the wound is employed when is debrided area is large. ${ }^{6,33}$

\section{Group A streptococcal necrotizing myositis}

Group A streptococcus (GAS) is the most common cause of cellulitis and various muscular infections like pyomyositis, subacute myositis, acute myositis, and malignant myositis. A severe or fatal form of the infection is called GAS necrotizing myositis or streptococcal myonecrosis or spontaneous streptococcal gangrenous myositis. ${ }^{5,6,8}$

Typically, young men are commonly affected, without a history of trauma or immunocompromised conditions. Although the route of infection is not known, it often starts as a sore throat, pharyngitis thus leading to bacteremia and spreading to the muscles. Nonsteroidal anti-inflammatory drugs act as a risk factor for the infection. ${ }^{5,6,34,35}$

Clinical features involve early stage flu-like symptoms, myalgia, and rash, which later on develop into severe pain of the muscle, fever, and local tense swelling. GAS necrotizing myositis might have multiple sites of infection, which progresses within 1 to 4 days to bacteremia, toxic shock syndrome, and multiorgan failure. As the intramuscular pressure increases in the infected muscle, it would lead to the development of compartment syndrome. ${ }^{5,6}$

Lab findings typically show leukocytosis along with elevated muscle enzymes. Muscle biopsy shows muscle necrosis and gram-positive cocci between the muscle bundles. ${ }^{5,6,32}$ Diagnosis of GAS necrotizing myositis depends on blood cultures and MRI; MRI is used to differentiate between fasciitis and necrotizing myositis. ${ }^{6,36}$

Immediate surgical exploration and debridement along with fasciotomy are required to reduce the increased compartment pressure. More often surgical excision should be repeated to remove the necrotic tissue and more frequently amputation is necessary. ${ }^{5,6,37}$

Intravenous antibiotic therapy with penicillin along with clindamycin has shown higher efficacy in reducing the bacterial burden during the stationary growth phase (Eagle effect), by inhibiting the toxin and other virulence factors production via blocking the protein synthesis. ${ }^{6,38} \mathrm{IV}$ immunoglobulin neutralizes the streptococcal exotoxins when used in patients with streptococcal toxic shock syndrome. GAS myositis has a mortality rate of nearly $85 \% .6,32,35,36$

\section{Group B streptococcal myositis}

$\mathrm{S}$. agalactiae can cause either PIM or myositis. The risk factors for group B streptococcal musculature infections include peripheral vascular disease, diabetes mellitus, alcoholism, malignancy, and immunocompromising conditions. Infection generally spreads from other body parts (foot ulcer, endocarditis). Treatment generally comprises penicillin and surgical debridement of the infected and necrotic muscles. ${ }^{6,39-41}$

\section{Clostridium species myositis}

Clostridium perfringens infection causes clostridial myonecrosis or gas gangrene. Infection occurs through various routes, which are traumatic wounds with soil contamination, vascular insufficiency involving the extremities, surgeries of bowel and biliary system, septic abortions, unhygienic injections of medications and illicit drugs. ${ }^{6,42}$

The presence of a foreign body and low oxygen concentrations promote anaerobic conditions that help the 
clostridium to convert from spore form to vegetative form, which releases the toxins for tissue damage and produces other systemic symptoms. ${ }^{6}$

Spontaneous clostridial myonecrosis can occur without a wound, because of C. septicum bacteremia caused by occult colon cancer, bowel infarction, and neutrophilic enterocolitis. ${ }^{6,43}$ Other species of Clostridium which are known to cause gas gangrene are C. novyi. C. histolyticum, C. sordellii. Clinical features include severe pain, edema, sweet odor discharge from the injured area (6 $\mathrm{h}$ to 3 days). The wound might turn from pale to bronze color due to hemorrhagic bullae. The presence of gas can be detected on radiographs of the infected tissues. ${ }^{6}$

Lab examination shows leukocytosis along with hemolytic anemia because of clostridial alpha-toxin and bacteremia is seen in $15 \%$ of the cases. Gram stain of the wound exudate usually shows numerous gram-positive bacilli with blunt ends and typically lacks neutrophils. Differential diagnosis should include fulminant myositis (GAS necrotizing myositis) and non-clostridial myositis. Crepitant cellulitis is commonly seen more superficially but should be considered while diagnosing clostridial myositis. ${ }^{6}$

Treatment consists of emergency surgical exploration along with the debridement and excision of the infected muscles and fasciotomies to relieve the pressure. Antibiotics should cover GAS necrotizing myositis and should be a combination of penicillin and clindamycin. ${ }^{6,44}$

Hyperbaric oxygen might have some benefit, as high oxygen concentrations inhibit the clostridial growth and thus reducing the alpha-toxin production. Hyperbaric oxygen can be used when there is incomplete surgical excision at paraspinal and abdominal areas. The mortality rate of clostridial myositis is between 20-25\%, often the survivors have disfiguring wounds. ${ }^{6,45,46}$

\section{Non-clostridial (Crepitant) myositis}

Non-clostridial myositis includes four categories, which are: ${ }^{1,4,6,46}$

- Anaerobic streptococcal myositis

- Synergistic non-clostridial myonecrosis

- Aeromonas hydrophila myonecrosis

- Infected vascular gangrene

\section{Anaerobic streptococcal myositis}

Anaerobic streptococcal myositis has similar characteristics to clostridial myonecrosis, which are considerable necrosis of the muscles, gas, and foul exudate from the infected muscles. Anaerobic streptococcal myositis can be differentiated from another myositis, by its slower evolution of infection over 1-4 days, overlying erythema, muscle contraction on stimulation along with numerous neutrophils in the exudate. Most common causative organisms include anaerobic streptococci (Peptostreptococcus), GAS, and S. aureus. Treatment includes gram-positive covering antibiotics (Penicillin, Vancomycin for staphylococcus) and surgical exploration and debridement. $5,6,46$

\section{Syngergistic non-clostridial myonecrosis}

Synergistic non-clostridial myonecrosis is the infection of the subcutaneous tissues and fascia, which might extend into the muscleand skin. Theinfection is often polymicrobial, including both aerobic and anaerobic organisms, like streptococci, Peptostreptococcus, E. coli, Klebsiella, Enterobacter, Bacillus cereus, and Bacteroides. Risk factors include diabetic patients, immunocompromised states like chemotherapy patients with neutropenia. Treatment includes complete surgical debridement of the infected tissues and broad-spectrum antibiotics. The mortality rate is high for patients with this infection. ${ }^{6,46}$

\section{Aeromonas hydrophila myonecrosis}

Aeromonas hydrophila, is an anaerobic gram-negative bacillus, which causes a rapid, progressive myonecrosis, after a penetrating trauma in a freshwater environment and is associated with fish or other aquatic animals. Myonecrosis has similarities to clostridial gas gangrene, due to its rapid onset (24 to $48 \mathrm{~h}$ ) and progression after trauma. ${ }^{6,46}$

Clinical features include pain, serosanguineous bullae, marked edema, gas in the fascial planes, and toxicity along with the history of exposure to freshwater directs towards Aeromonas diagnosis. Treatment comprises surgical debridement and antibiotic therapy. Antimicrobials like gentamicin, tobramycin, carbapenems, and ciprofloxacin are most effective against Aeromonas. Vibrio vulnificus, causes myositis and is associated with exposure to saltwater. ${ }^{6,46}$ As per literature review done by Koth et al., (2012) of Aeromonas hydrophila soft tissue infections has found that these infections occur following motor vehicle crashes, farmyard injuries, puncture injuries, and mud football injuries involving wound contamination from aquatic and non-aquatic environments. ${ }^{47}$

\section{Infected vascular gangrene}

Infected vascular gangrene is a mixed infection in a muscle group or a limb that has arterial insufficiency, frequently seen in diabetes mellitus. The most commonly seen bacterial species are Proteus, Bacteroides, and anaerobic streptococci. Even though the infection does not spread beyond the vascular gangrene, foul-smelling pus and gas formation are notable. Bacillus cereus causes myonecrosis due to thrombosis of the arterial grafts 
with crepitus, along with aggressive post-traumatic infections. ${ }^{6,46,48}$

\section{Other forms of bacterial myositis}

Some of the other bacteria not discussed above can sporadically cause myalgias, myositis, myopathy, and rhabdomyolysis. Although endocarditis might cause diffuse myalgias, diagnosis is established by blood cultures and echocardiography. Syphilis might also be associated with myalgias and should be confirmed by microhemagglutination - Treponema pallidum test.6,49

Other causes of myalgias are Rickettsia rickettsii (Rocky Mountain spotted fever), Francisella tularensis (Tularemia), Borrelia burgdorferi (Lyme disease), and diagnosis is based on serological tests., ${ }^{6,50,51}$ Muscle involvement in Mycobacterium infections is seen in $<1 \%$ of the cases. Myositis develops slowly and is insidious, physical exam shows a mass or swelling in the muscle and adenopathy is often absent., 62,53

Acute rhabdomyolysis during bacterial infections occurs less commonly. Legionella is the most common bacteria associated with rhabdomyolysis development. Less often bacteria like staphylococci, streptococci, Salmonella, Leptospira, Neisseria meningitides, and Mycoplasma pneumoniae are also involved in rhabdomyolysis. ${ }^{6,54-57}$

\section{Viral myositis}

The viral agents are the most common cause of nonbacterial infectious myositis. Clinical symptoms involve myalgia's, polymyositis, and rhabdomyolysis. Among viruses, influenza is the most frequent causative agent reported to cause viral myositis. Other viruses that are widely involved in myositis are shown in Table 2.3,6

\section{Influenza}

Influenza usually presents with cough, fever, rhinorrhea, and myalgia's (diffuse, self-limiting). In the late stage of the infection, patients develop "acute benign myositis", with typical symptoms like pain, tenderness, and swelling (gastrocnemius and soleus muscles); difficulty in walking is also noted. Influenza-associated myositis is seen more often in children as the immature muscle cells are more prone to infection. ${ }^{3,58,59}$

Among children, boys are more affected than girls (2:1). It has a mean presentation on day 3 and influenza type $B$ is commonly seen than type $\mathrm{A}$, due to the presence of a glycoprotein in Type B strains. Diagnosis is confirmed by the clinical history, detection of virus by polymerase chain reaction (PCR) test of the nasopharyngeal secretions. Symptoms usually resolve in one week but may last till one month. Treatment includes symptomatic care and often may develop into life-threatening rhabdomyolysis, with an increase in creatine phosphokinase and myoglobin-induced acute renal failure which is commonly seen with influenza A. ${ }^{3,46,58}$

\section{Coxsackievirus}

Pleurodynia is caused by group B coxsackievirus (rarely by group A) and less often by enteric cytopathogenic human orphan (ECHO 1, 6,9, 16, and 19) viruses. The symptoms include acute onset of sharp chest pain over the sternum or lower ribs, fever, muscle tenderness, and abdominal pain might be present. Coxsackie A9, B2, B6, and echoviruses 9,11 can also cause myositis in skeletal muscles and might develop into rhabdomyolysis with elevated muscle enzymes and myoglobinuria. Diagnosis is based on clinical features, serologic evaluation, and culture of the virus from either pharyngeal or fecal samples. Treatment is symptomatic. $3,46,59,60$

\section{Human immunodeficiency virus}

Clinical features of HIV infection are polymyositis, weakness, myalgia's, and elevated muscle enzyme levels. Patients with HIV might initially present with polymyositis, which will lead to the diagnosis. Patients with immunocompromised and low CD4+ T lymphocytes are more prone to develop several other forms of myopathies like inclusion-body myositis, wasting, vasculitis, infiltrative lymphocytosis syndrome, antiretroviral medications (mitochondrial myopathy), myasthenia syndrome, and skeletal muscle malignancy. $3,46,61$

While doing work-up for viral myositis, HIV testing should be included. Serum creatine phosphokinase is increased, muscle biopsy and electromyographic changes might aid in making a diagnosis. Management includes supportive care and treating the underlying myositis causative agent. Antiretroviral therapy should be initiated if the patient is diagnosed for the first time. Few cases of myositis might develop into rhabdomyolysis. ${ }^{3,46,62}$

\section{Coronaviruses}

Coronavirus disease-2019 (COVID-19), is caused by severe acute respiratory syndrome coronavirus-2 (SARSCoV-2). Although it is known to cause life-threatening respiratory illnesses, there is increasing evidence of multisystem involvement in neurological, gastrointestinal, and cardiac systems. Although myalgia's are common in COVID-19 patients, elevated creatine kinase levels are reported in SARS patients. Zhang et al. reported a case of COVID-19 associated myositis involving a proximal limb, bulbar, and facial muscles, which was treated with $1000 \mathrm{mg}$ intravenous methylprednisolone for 5 days. ${ }^{63}$ 
Mehan et. al. reported that $78 \%$ (7 out of 9) COVID-19 patients who had MRI of the spine showed evidence of paraspinal (only in the lumbar spine) myositis featuring intramuscular edema and enhancement. The study concluded that a high frequency of myositis in COVID-19 patients reported myalgia in a small series. ${ }^{64}$ Beydon et al. demonstrated that the association of myositis with interstitial pneumonitis can be seen in COVID-19 patients or autoimmune myositis. ${ }^{65}$

\section{Other viruses}

Human T-cell lymphotropic virus type (HTLV-1) causes "adult T-cell leukemia/lymphoma and tropical spastic paraparesis/HTLV-1 associated myelopathy”. Hepatitis $\mathrm{B}$ and $\mathrm{C}$ viruses are also implicated in the development of polymyositis. Adenovirus is involved in causing myositis, myocarditis and rhabdomyolysis. Parvovirus B19 leads to myositis along with fever, diffuse rash which involves cheeks. West Nile virus also causes myositis along with neurological symptoms. Other viral agents that are involved in the myositis are shown in Table 2. Diagnosis is usually based on the clinical picture, serological studies, and cultures of the nasopharyngeal and stool samples. Muscle biopsies, immunofluorescent or PCR studies, electron microscopy are often used in the diagnosis of the causative virus. ${ }^{3,46,66-68}$

\section{Fungal Myositis}

Fungal infections of the musculature are relatively uncommon. Most of the cases are seen in immunocompromised patients and the diagnosis is established through biopsy and culture of the specimens. ${ }^{3}$

\section{Candidiasis}

The most common cause of fungal myositis is candida and is usually seen in immunosuppressive patients (chemotherapy and broad-spectrum antibiotic usage). $C$. tropicalis, C. albicans, C. krusei are the involved species in infecting the musculature. Clinical features include fever, rash, muscle tenderness, diffuse, micro-abscesses or focal, and fungal abscesses of the muscles might also occur. Diagnosis is established by imaging (CT, MRI, ultrasound), muscle biopsy, histopathology and fungal cultures. Management is with amphotericin B, azoles, or echinocandin and surgical drainage for large collections in the muscles. ${ }^{3,8}$

\section{Cryptococcosis}

Cryptococcus neoformans causes myositis through the dissemination of the inhaled organisms. Most of the cases are seen in transplant recipients and HIV patients. Clinical features include pain and swelling of the muscles in the lower limbs. Diagnosis involves muscle biopsy, lumbar puncture for CNS involvement, positive cryptococcal serum antigen, and blood cultures. Treatment is with amphotericin B, flucytosine for multifocal disease, fluconazole for localized disease, and surgical drainage for purulent collections. ${ }^{3,69}$

\section{Histoplasmosis}

Histoplasma capsulatum is dimorphic fungi and causes myositis through dissemination in HIV and immunocompromised patients. Diagnosis is established through biopsy, histopathology cultures of the fungus, and antigen testing. Treatment is with amphotericin B and surgical drainage for collections. ${ }^{3,70}$

\section{Aspergillosis and other fungi}

Aspergillus spp causes myositis in immunocompromised patients, similar to other fungal causative agents. Diagnosis is with biopsy and fungal culture, fungal antigen testing. Treatment is with voriconazole or amphotericin B and surgical debridement for necrotic tissue. Other causes of fungal myositis are shown in Table $2,3,6,71$

\section{Parasitic agents}

Various parasites encyst in the muscles, thus causing myositis. Travel history is important in diagnosing the parasitic infections that are acquired abroad. History of food ingestion along with eosinophilia points towards a parasitic causative agent. Different parasitic agents that are involved in causing myositis are shown in Table 2., ${ }^{3,6}$

\section{Trichinosis}

Trichinella spp, especially T. spiralis, infects humans through undercooked meat, like pork, bear, cougar, and wild boar, thus the larvae encyst in the striated muscles. Clinical features include gastrointestinal symptoms, fever, myalgia's, muscle weakness and swelling (extraocular muscles, head, and neck muscles). Although the infection is self-limiting, complications like myocarditis can occur due to encysted larvae. Diagnosis is through detailed dietary history, eosinophilia, raised muscle-related enzymes, serological testing for antibodies, radiographs for encysted larvae, and muscle biopsy. Treatment involves albendazole or mebendazole, severe myositis should include the addition of corticosteroids. ${ }^{3,72,73}$

\section{Cysticercosis}

Taenia solium, pork tapeworm infects humans through contaminated food and water, thus leading to cysticercosis. Eggs develop into invasive larvae, which move through the intestinal wall and move to CNS, subcutaneous tissues and 
muscles. Symptoms mayinclude seizures, myalgias, myositis, and weakness due to inflammatory reactions from the dying cysts. Imaging (MRI, CT or ultrasound), shows scolex in a clear cyst, thus aiding in the diagnosis. Radiographs of the cysts have a "puffed rice" or "spindle-shaped" appearance. Serological testing of the cerebrospinal fluid or blood is also used in making the diagnosis. Treatment is with albendazole or praziquantel and surgical excision for large intramuscular lesions. ${ }^{3,74}$

\section{Toxoplasmosis}

Toxoplasma gondii, is acquired through ingestion of undercooked meat (pork or lamb), containing tissue cysts or oocysts from cat feces. An acute infection might be asymptomatic or may develop into a fever, malaise, myalgia's and cervical adenopathy. Immunocompromised patients, T-cell deficiencies, therapy with corticosteroids and AIDS patients might develop polymyositis and myocarditis. Severe infection symptoms include wasting, fasciculation's, fever, encephalitis and multiorgan failure. Diagnosis is with clinical history, serologic testing, muscle biopsy along with immunocytochemistry, and microscopy, and isolating organisms from tissue culture. Therapy is with sulfadiazine and pyrimethamine, in early stages of myositis, and steroids should be included in the late stages of the disease.,75

\section{Microsporidiosis}

Microsporidia spp, route of infection is not clear, might be through insect bites, contaminated water, or undercooked meat. Immunosuppressive states, therapy with corticosteroids and tumor necrosis factor antagonists, and AIDS patients increases the risk for microsporidiosis. Clinical features include fever, muscle pain, wasting, and weakness along with elevated creatine kinase. Diagnosis is based on muscle biopsy along with light and electron microscopy. Treatment is with albendazole and itraconazole is added for Annicaliia vesicularum myositis. ${ }^{3,76}$

\section{Conclusions}

Infectious myositis is caused by bacterial, viral, fungal and parasitic organisms. Pathogenesis of myositis is either via direct infection of the muscle or immune-mediated injury. Bacterial and fungal myositis is usually confined to a muscle group, while viral myositis is diffuse and parasitic myositis often has a travel history along with eosinophilia. Diagnosis is with clinical features, laboratory, serology, cultures, and imaging. Treatment is with appropriate antibiotics and involves a holistic approach from various specialties.

\section{Corresponding author:}

Sireesha Murala MD

Department of Neurology

University of Missouri, Columbia, Missouri

Phone: 573-882-1515

siri.murala@gmail.com

\section{References}

1. Brook I. Microbiology and management of soft tissue and muscle infections. Int J Surg. 2008 Aug;6(4):32838. doi: 10.1016/j.ijsu.2007.07.001. Epub 2007 Jul 15. PMID: 17720643.

2. Crum NF. Bacterial pyomyositis in the United States. Am J Med. 2004 Sep 15;117(6):420-8. doi: 10.1016/j. amjmed.2004.03.031. PMID: 15380499.

3. Crum-Cianflone NF. Nonbacterial myositis. Curr Infect Dis Rep. 2010 Sep;12(5):374-82. doi: 10.1007/ sl1908-010-0118-z. PMID: 21308520.

4. Pasternack, M.S., and M. N. Swartz. Mandell, Douglas, and Bennett's Principles and Practice of Infectious Diseases, 6th Edition Edited by Gerald L. Mandell, John E. Bennett, and Raphael Dolin Philadelphia: Elsevier Churchill Livingstone, 2005. 3661 pp., illustrated. Clin Infect Dis. 2005 Jul 15;41(2):277. doi: 10.1086/431221. Epub 2005 Jul 15. ISBN: 9781455748013.

5. Crum-Cianflone NF. Infection and musculoskeletal conditions: Infectious myositis. Best Pract Res Clin Rheumatol. 2006 Dec;20(6):1083-97. doi: 10.1016/j. berh.2006.08.005. PMID: 17127198.

6. Crum-Cianflone NF. Bacterial, fungal, parasitic, and viral myositis. Clin Microbiol Rev. 2008 Jul;21(3):47394. doi: 10.1128/CMR.00001-08. PMID: 18625683.

7. Wortmann RL. Inflammatory diseases of mucle and other myopathies. In: Harris ED, Budd RC, Firestein GS, et al., editors. Kelley's textbook of rheumatology. 7th edition. Philadelphia: Elsevier Saunders; 2005. pp. 130935.

8. Kallen PS, Louie JS, Nies KM, Bayer AS. Infections myositis and related syndromes. Semin Arthritis Rheum. 1982 May;1l(4):421-39. doi: 10.1016/00490172(82)90029-4. PMID: 7100932.

9. Peng SL. Rheumatic manifestations of parasitic diseases. Semin Arthritis Rheum. 2002 Feb;31(4):228-47. doi: 10.1053/sarh.2002.30441. PMID: 11836656.

10. Habeych ME, Trinh T, Crum-Cianflone NF. Purulent infectious myositis (formerly tropical pyomyositis). J Neurol Sci. 2020 Jun 15;413:116767. doi: 10.1016/j. jns.2020.116767. Epub 2020 Mar 5. PMID: 32172014. 
11. Parasca I, Damian L, Albu A. Infectious muscle disease. Rom J Intern Med. 2006;44(2):131-41. PMID: 17236294.

12. Miyake, H. Beitrage (Beitraege) zur Kenntnis der sogenannten Myositis Infectiosa. Mitt. Grenzgeb. Med. Chir. 1904;13:155-198.

13. Smith IM, Vickers AB. Natural history of 338 treated and untreated patients with staphylococcal septicaemia (1936-1955). Lancet. 1960 Jun 18;1(7138):1318-22. PMID: 13831996.

14. Jayoussi R, Bialik V, Eyal A, Shehadeh N, Etzioni A. Pyomyositis caused by vigorous exercise in a boy. Acta Paediatr. 1995 Feb;84(2):226-7. doi: 10.1111/j.1651-2227.1995. tbl3618.x. PMID: 7756817.

15. Domínguez-Pinilla N, Villora-Morcillo N, Caro-Barri A, Vivanco-Martinez J, Gonzalez-Granado LI. Pyomyositis and bacteremia due to Staphylococcus aureus as onset of acute promyelocytic leukemia. Pediatr Int. 2015 Oct;57(5):1053-4. doi: 10.1111/ped.12740. PMID: 26508198.

16. Falesi M, Regazzoni BM, Wyttenbach M, Wyttenbach R, Bianchetti MG, Riavis M. Primary pelvic pyomyositis in a neonate. J Perinatol. 2009 Dec;29(12):830-1. doi: 10.1038/jp.2009.106. PMID: 19935734.

17. Koudela K Jr, Koudela KSr, Koudelová J, Kunesová M. Sekundární pyomyozitida kycelních svalů (nontropical pyomyositis) [Secondary pyomyositis of hip muscles (nontropical pyomyositis)]. Acta Chir Orthop Traumatol Cech. 2008 Jun;75(3):196-204. Czech. PMID: 18601818.

18. Karmazyn B, Kleiman MB, Buckwalter K, Loder RT, Siddiqui A, Applegate KE. Acute pyomyositis of the pelvis: the spectrum of clinical presentations and MR findings. Pediatr Radiol. 2006 Apr;36(4):338-43. doi: 10.1007/ s00247-005-0082-1. Epub 2006 Feb 10. PMID: 16474970.

19. Kiran M, Mohamed S, Newton A, George H, Garg N, Bruce C. Pelvic pyomyositis in children: changing trends in occurrence and management. Int Orthop. 2018 May;42(5):1143-1147. doi: 10.1007/s00264-017-3746-1. Epub 2017 Dec 30. PMID: 29289987.

20. Saeed K, Esposito S, Gould I, et al. International Society of Antimicrobial Chemotherapy. Hot topics in necrotising skin and soft tissue infections. Int J Antimicrob Agents. 2018 Jul;52(1):1-10. doi: 10.1016/j.jjantimicag.2018.02.012. Epub 2018 Mar 6. PMID: 29501822.

21. Sauler A, Saul T, Lewiss RE. Point-of-care ultrasound differentiates pyomyositis from cellulitis. Am J Emerg Med. 2015 Mar;33(3):482.e3-5. doi: 10.1016/j. ajem.2014.08.064. Epub 2014 Aug 29. PMID: 25245285.
22. Roberts S, Chambers S. Diagnosis and management of Staphylococcus aureus infections of the skin and soft tissue. Intern Med J. 2005 Dec;35 Suppl 2:S97-105. doi: 10.1111/j.1444-0903.2005.00983.x. PMID: 16271065.

23. Maron R, Levine D, Dobbs TE, Geisler WM. Two cases of pott disease associated with bilateral psoas abscesses: case report. Spine (Phila Pa 1976). 2006 Jul 15;31(16):E561-4. doi: 10.1097/01. brs.0000225998.99872.7f. PMID: 16845344.

24. Santaella RO, Fishman EK, Lipsett PA. Primary vs secondary iliopsoas abscess. Presentation, microbiology, and treatment. Arch Surg. 1995 Dec;130(12):1309-13. doi: 10.1001/archsurg.1995.01430120063009. PMID: 7492279.

25. Walsh TR, Reilly JR, Hanley E, Webster M, Peitzman A, Steed DL. Changing etiology of iliopsoas abscess. Am J Surg. 1992 Apr;163(4):413-6. doi: 10.1016/0002-9610(92)90043-q. PMID: 1532700.

26. Kern L, Rassbach C, Ottolini M. Streptococcal pyomyositis of the psoas: case reports and review. Pediatr Emerg Care. 2006 Apr;22(4):250-3. doi: 10.1097/01. pec.0000210177.48386.e7. PMID: 16651916.

27. Ricci MA, Rose FB, Meyer KK. Pyogenic psoas abscess: worldwide variations in etiology. World J Surg. 1986 Oct;10(5):834-43. doi: 10.1007/BF01655254. PMID: 3776220 .

28. Baier PK, Arampatzis G, Imdahl A, Hopt UT. The iliopsoas abscess: aetiology, therapy, and outcome. Langenbecks Arch Surg. 2006 Aug;391(4):411-7. doi: 10.1007/s00423-006-0052-6. Epub 2006 May 6. PMID: 16680473.

29. Garner JP, Meiring PD, Ravi K, Gupta R. Psoas abscess - not as rare as we think? Colorectal Dis. 2007 Mar;9(3):269-74. doi: 10.1111/j.1463-1318.2006.01135.x. PMID: 17298628.

30. Blumberg, H.M., Burman, W.J., Chaisson, R.E., et al. American thoracic society/centers for disease control and prevention/infectious diseases society of america: Treatment of tuberculosis. Am J Respir Crit Care Med. 2003;167(4):603-62. Epub 2003/02/18. doi: 10.1164/ rccm.167.4.603. PMID: 12588714.

31. Wells RD, Bebarta VS. Primary iliopsoas abscess caused by community-acquired methicillin-resistant Staphylococcus aureus. Am J Emerg Med. 2006 Nov;24(7):8978. doi: 10.1016/j.ajem.2006.03.030. PMID: 17098125.

32. Adams EM, Gudmundsson S, Yocum DE, et al. Streptococcal myositis. Arch Intern Med. 1985 Jun;145(6):1020-3. PMID: 3890787. 
33. Pannaraj PS, Hulten KG, Gonzalez BE, et al. Infective pyomyositis and myositis in children in the era of community-acquired, methicillin-resistant Staphylococcus aureus infection. Clin Infect Dis. 2006 Oct 15;43(8):953-60. doi: 10.1086/507637. Epub 2006 Sep 1. PMID: 16983604.

34. Hird B, Byrne K. Gangrenous streptococcal myositis: case report. J Trauma. 1994 Apr;36(4):589-91. PMID: 8158727.

35. Jahnson L, Berggren L, Björsell-Ostling E, et al. Streptococcal myositis. Scand J Infect Dis. 1992;24(5):6615. doi: 10.3109/00365549209054654. PMID: 1465586.

36. Roggiani, M., and P. M. Schlievert. 1994. Streptococcal toxic shock syndrome, including necrotizing fasciitis and myositis. Curr. Opin. Infect. Dis. 7:423-426.

37. Wagner JG, Schlievert PM, Assimacopoulos AP, et al. Acute group G streptococcal myositis associated with streptococcal toxic shock syndrome: case report and review. Clin Infect Dis. 1996 Nov;23(5):1159-61. doi: 10.1093/clinids/23.5.1159. PMID: 8922817.

38. Stevens DL, Gibbons AE, Bergstrom R, et al. The Eagle effect revisited: efficacy of clindamycin, erythromycin, and penicillin in the treatment of streptococcal myositis. J Infect Dis. 1988 Jul;158(1):23-8. doi: 10.1093/ infdis/158.1.23. PMID: 3292661.

39. Back SA, O’Neill T, Fishbein G, et al. A case of group B streptococcal pyomyositis. Rev Infect Dis. 1990 Sep-Oct;12(5):784-7. doi: 10.1093/clinids/12.5.784. PMID: 2146739.

40. Caldwell DS, Kernodle GW Jr, Seigler HF. Pectoralis pyomyositis: an unusual cause of chest wall pain in a patient with diabetes mellitus and rheumatoid arthritis. J Rheumatol. 1986 Apr;13(2):434-6. PMID: 3522899.

41. Walling DM, Kaelin WG Jr. Pyomyositis in patients with diabetes mellitus. Rev Infect Dis. 1991 SepOct;13(5):797-802. doi: 10.1093/clinids/13.5.797. PMID: 1962087.

42. Bangsberg DR, Rosen JI, Aragón T, et al. Clostridial myonecrosis cluster among injection drug users: a molecular epidemiology investigation. Arch Intern Med. 2002 Mar 11;162(5):517-22. doi: 10.1001/archinte.162.5.517. PMID: 11871919.

43. El-Masry S. Spontaneous gas gangrene associated with occult carcinoma of the colon: a case report and review of literature. Int Surg. 2005 Sep-Oct;90(4):245-7. PMID: 16548324.

44. Stevens DL, Laine BM, Mitten JE. Comparison of single and combination antimicrobial agents for prevention of experimental gas gangrene caused by Clos- tridium perfringens. Antimicrob Agents Chemother. 1987 Feb;31(2):312-6. doi: 10.1128/aac.31.2.312. PMID: 2882732 ; PMCID: PMC174712.

45. Hart GB, Lamb RC, Strauss MB. Gas gangrene. J Trauma. 1983 Nov;23(11):991-1000. doi: 10.1097/00005373-198311000-00006. PMID: 6355502.

46. Pasternack MS, Swartz MN. Myositis and Myonecrosis. Mandell, Douglas, and Bennett's Principles and Practice of Infectious Diseases. 2015:1216-1225.e2. doi: 10.1016/B978-1-4557-4801-3.00096-5. Epub 2014 Oct 31. PMCID: PMC7151864.

47. Koth K, Boniface J, Chance EA, Hanes MC. Enterobacter asburiae and Aeromonas hydrophila: soft tissue infection requiring debridement. Orthopedics. 2012 Jun;35(6):e996-9. doi: 10.3928/01477447-20120525-52. PMID: 22691684.

48. Brett MM, Hood J, Brazier JS, Duerden BI, Hahné SJ. Soft tissue infections caused by spore-forming bacteria in injecting drug users in the United Kingdom. Epidemiol Infect. 2005 Aug;133(4):575-82. doi: 10.1017/ s0950268805003845. PMID: 16050501.

49. Durston, J.H., Jefferiss, F.J. Syphilitic myositis. The British journal of venereal diseases. 1975;51(2):141-2. doi: 10.1136/sti.51.2.141. PMID: 1131681.

50. Eliasson H, Bäck E. Myositis and septicaemia caused by Francisella tularensis biovar holarctica. Scand J Infect Dis. 2003;35(8):510-1. doi: 10.1080/00365540310000328328. PMID: 14514156.

51. Holmgren, A.R., Matteson, E.L. Lyme myositis. Arthritis Rheum. 2006;54(8):2697-700. Epub 2006/07/28. doi: 10.1002/art.22007. PMID: 16871548.

52. Wang JY, Lee LN, Hsueh PR, et al. Tuberculous myositis: a rare but existing clinical entity. Rheumatology (Oxford). 2003 Jul;42(7):836-40. doi: 10.1093/rheumatology/keg228. PMID: 12826705.

53. Wang WY, Lin FC, Tsao TY, Lu JJ. Tuberculous myositis: an unusual presentation of extrapulmonary tuberculosis. J Microbiol Immunol Infect. 2007 Feb;40(1):7982. PMID: 17332912.

54. Berger RP, Wadowksy RM. Rhabdomyolysis associated with infection by Mycoplasma pneumoniae: a case report. Pediatrics. 2000 Feb;105(2):433-6. doi: 10.1542/ peds.105.2.433. PMID: 10654971.

55. van Deuren M, Neeleman C, Assmann KJ, Wetzels JF, van der Meer JW. Rhabdomyolysis during the subacute stage of meningococcal sepsis. Clin Infect Dis. 1998 Jan;26(1):214-5. doi: 10.1086/517026. PMID: 9455554. 
56. Naschitz JE, Yeshurun D, Shagrawi I. Rhabdomyolysis in pneumococcal sepsis. Am J Med. 1989 Oct;87(4):479-80. doi: 10.1016/s0002-9343(89)80842-3. PMID: 2801740.

57. Solbrig MV, Sher JH, Kula RW. Rhabdomyolysis in leptospirosis (Weil's disease). J Infect Dis. 1987 Oct;156(4):692-3. doi: 10.1093/infdis/156.4.692. PMID: 3624913.

58. Agyeman P, Duppenthaler A, Heininger U, Aebi C. Influenza-associated myositis in children. Infection. 2004 Aug;32(4):199-203. doi: 10.1007/s15010-004-4003-2. PMID: 15293074.

59. Yoshino M, Suzuki S, Adachi K, Fukayama M, Inamatsu T. High incidence of acute myositis with type A influenza virus infection in the elderly. Intern Med. 2000 May;39(5):431-2. doi: 10.2169/internalmedicine.39.431. PMID: 10830190.

60. Fodili F, van Bommel EF. Severe rhabdomyolysis and acute renal failure following recent Coxsackie B virus infection. Neth J Med. 2003 May;61(5):177-9. PMID: 12916546.

61. Authier FJ, Chariot P, Gherardi RK. Skeletal muscle involvement in human immunodeficiency virus (HIV)infected patients in the era of highly active antiretroviral therapy (HAART). Muscle Nerve. 2005 Sep;32(3):247-60. doi: 10.1002/mus.20338. PMID: 15902690.

62. Chariot P, Ruet E, Authier FJ, Lévy Y, Gherardi R. Acute rhabdomyolysis in patients infected by human immunodeficiency virus. Neurology. 1994 Sep;44(9):1692-6. doi: 10.1212/wnl.44.9.1692. PMID: 7936298.

63. Zhang H, Charmchi Z, Seidman RJ, Anziska Y, Velayudhan V, Perk J. COVID-19-associated myositis with severe proximal and bulbar weakness. Muscle Nerve. 2020 Sep;62(3):E57-E60. doi: 10.1002/mus.27003. Epub 2020 Jul 3. PMID: 32535934; PMCID: PMC7323133.

64. Mehan WA, Yoon BC, Lang M, Li MD, Rincon S, Buch K. Paraspinal Myositis in Patients with COVID-19 Infection. AJNR Am J Neuroradiol. 2020 Oct;41(10):19491952. doi: 10.3174/ajnr.A671l. Epub 2020 Aug 6. PMID: 32763902 .

65. Beydon M, Chevalier K, Al Tabaa O, Hamroun S, Delettre AS, Thomas M, Herrou J, Riviere E, Mariette X. Myositis as a manifestation of SARS-CoV-2. Ann Rheum Dis. 2020 Apr 23:annrheumdis-2020-217573. doi: 10.1136/ annrheumdis-2020-217573. Epub ahead of print. PMID: 32327427.

66. Bowles NE, Ni J, Kearney DL, et al. Detection of viruses in myocardial tissues by polymerase chain reac- tion. evidence of adenovirus as a common cause of myocarditis in children and adults. J Am Coll Cardiol. 2003 Aug 6;42(3):466-72. doi: 10.1016/s0735-1097(03)00648-x. PMID: 12906974.

67. Di Muzio A, Bonetti B, Capasso M, Panzeri L, Pizzigallo E, Rizzuto N, Uncini A. Hepatitis C virus infection and myositis: a virus localization study. Neuromuscul Disord. 2003 Jan;13(1):68-71. doi: 10.1016/s09608966(02)00184-0. PMID: 12467735.

68. Smith RD, Konoplev S, DeCourten-Myers G, Brown T. West Nile virus encephalitis with myositis and orchitis. Hum Pathol. 2004 Feb;35(2):254-8. doi: 10.1016/j. humpath.2003.09.007. PMID: 14991545.

69. Sharma M, Khatib R, Jones BA, Fakih MG. Cryptococcus neoformans myositis without dissemination. Scand J Infect Dis. 2002;34(11):858-9. doi: 10.1080/0036554021000026945. PMID: 12578163.

70. Voloshin DK, Lacomis D, McMahon D. Disseminated histoplasmosis presenting as myositis and fasciitis in a patient with dermatomyositis. Muscle Nerve. 1995 May;18(5):531-5. doi: 10.1002/mus.880180509. PMID: 7739641.

71. Javier RM, Sibilia J, Lugger AS, Natarajan-Ame S, Kuntz JL, Herbrecht R. Fatal Aspergillus fumigatus Myositis in an immunocompetent patient. Eur J Clin Microbiol Infect Dis. 2001 Nov;20(11):810-3. doi: 10.1007/ s100960100607. PMID: 11783699.

72. Basuroy R, Pennisi R, Robertson T, Norton R, Stokes J, Reimers J, Archer J. Parasitic myositis in tropical Australia. Med J Aust. 2008 Feb 18;188(4):254-6. PMID: 18279140.

73. Watt G, Saisorn S, Jongsakul K, Sakolvaree Y, Chaicumpa W. Blinded, placebo-controlled trial of antiparasitic drugs for trichinosis myositis. J Infect Dis. 2000 Jul;182(1):371-4. doi: 10.1086/315645. Epub 2000 Jun 30. PMID: 10882628.

74. Ergen FB, Turkbey B, Kerimoglu U, Karaman K, Yorganc K, Saglam A. Solitary cysticercosis in the intermuscular area of the thigh: a rare and unusual pseudotumor with characteristic imaging findings. J Comput Assist Tomogr. 2005 Mar-Apr;29(2):260-3. doi: 10.1097/01. rct.0000157746.87488.6a. PMID: 15772549.

75. Plonquet A, Bassez G, Authier FJ, Dray JM, Farcet JP, Gherardi RK. Toxoplasmic myositis as a presenting manifestation of idiopathic CD4 lymphocytopenia. Muscle Nerve. 2003 Jun;27(6):761-5. doi: 10.1002/mus.10376. PMID: 12766990. 
76. Curry A, Beeching NJ, Gilbert JD, Scott G, Rowland PL, Currie BJ. Trachipleistophora hominis infection in the myocardium and skeletal muscle of a patient with AIDS. J Infect. 2005 Oct;51(3):el39-44. doi: 10.1016/j. jinf.2004.11.006. Epub 2004 Dec 23. PMID: 16230193. 